\title{
Correction: Group formation under limited resources: narrow basin of equality
}

\section{Dongryul Lee ${ }^{1} \&$ Pilwon Kim²}

Correction to: Palgrave Communications; https://doi.org/10.1057/s41599-018-0146-0, Published online 17 July 2018.

In the original published HTML version of this Article, some of the characters in the equations were not appearing correctly. This has now been corrected in the HTML version.

Published online: 14 August 2018

\begin{abstract}
(c) (i) Open Access This article is licensed under a Creative Commons Attribution 4.0 International License, which permits use, sharing, adaptation, distribution and reproduction in any medium or format, as long as you give appropriate credit to the original author(s) and the source, provide a link to the Creative Commons license, and indicate if changes were made. The images or other third party material in this article are included in the article's Creative Commons license, unless indicated otherwise in a credit line to the material. If material is not included in the article's Creative Commons license and your intended use is not permitted by statutory regulation or exceeds the permitted use, you will need to obtain permission directly from the copyright holder. To view a copy of this license, visit http://creativecommons.org/licenses/by/4.0/.
\end{abstract}

(C) The Author(s) 2018

\footnotetext{
${ }^{1}$ Department of Economics, Sungshin University, 1023 Soojung BIdg. B, Seoul 136-742, Korea. ${ }^{2}$ Department of Mathematical Sciences, School of Natural Science, UNIST (Ulsan National Institute of Science and Technology), Ulsan 689-798, Korea. Correspondence and requests for materials should be addressed to P.K. (email: pwkim@unist.ac.kr)
} 